\title{
The Problems of Absorption of the European Structural and Investment Funds Related to the Cohesion Policy during the Programming Period 2014-2020
}

Florian MARIN ${ }^{1}$

\begin{abstract}
The article proceeds to the inventory of the main problems with which the absorption related to the operational programs financed by the Cohesion Policy faces, these being proved by the data specific to the absorption. It addresses the problems identified at a systemic level with a descriptive approach to the variables that negatively affect the absorption process. The article thus describes the existence of a range of problems such as the need for co-financing, a difficult access to financing for the less developed counties or the existence of a low and unbalanced level of absorption at the thematic objective level of Cohesion Policy.
\end{abstract}

Keyword: European funds, Cohesion Policy, projects, programming period 2014 -2020, operation programs

JEL classification: E61, M10

DOI: $10.24818 /$ RMCI.2019.5.530

\section{Introduction}

In a European Union where the need for reform is increasingly present, amid geopolitical tensions that significantly test the unity and the European project or where regional disparities seem to deepen. Add to this the tensions generated by Brexit or the US-China trade war, which are difficult to manage. The European Union is thus in a context full of challenges, deriving both from within and from outside. Maximizing the use of the instruments with which the European Union operates is in this context an imperative issue, precisely to generate confidence in the European project and its potential.

The need to build confidence in the European future must be realized in a strategic and programmatic framework that integrates the development differences from west to east but also the potential or competitive advantages that the European Union enjoys. This context manifests itself after a strategic failure of the European Commission, a failure called the Lisbon Strategy, which was not achieved during the programming period 2007 - 2013. With a much more weighted and adapted to the specificity of the European Union and with a much more adaptable level, the Europe 2020 Strategy was launched. This regulates the method of strategic approach at the level of the programming period 2014 - 2020, being carried out under the pressure of a cumulative crisis, the most important being the financial crisis.

\footnotetext{
${ }^{1}$ Academy of Economic Studies, Bucharest, Romania; marinflorian_21@yahoo.com
} 
The Europe 2020 strategy is complemented by a series of thematic approaches that ensure complementarity between the investments promoted by the European Commission. The concrete way in which Europe 2020 helps Member States targets European policies that have as their concrete leverage European funds. Specifically, two of the most important policies are the Cohesion Policy and the Common Agricultural Policy. These two policies are considered to be some of the most important policies at European level, benefiting from significant budget tires through European funds. European funds are by far the most notorious instrument with which the European Union operates, being one of the most used by the Member States. Being managed on the basis of the shared management principle, they represent an investment source that synergistically integrates both the development objectives of the Member State and those of the European Commission.

European funds have thus become an important source of funding at Member State level, with financing architectures being intensely concerned about the integration of European funding sources in order to increase the potential and the investment dimension. However, although the European funds deliver a high level of importance, they also benefit from a set of rigor and responsibilities that require a financial and institutional effort that is not to be neglected. The ability of Member States to adapt to the specificity of European funds for full and efficient use is different, hence there are different absorption rates from one Member State to another. The macroeconomic context, the institutional architecture, the institutional architecture, the level of state involvement are elements that influence the quality and quantity of absorption.

\section{Methodology}

In the present article we propose an inventory of the main problems with which the process of absorption of the European funds from the Cohesion Policy faces. In order to achieve this, we proceeded to collect, organize and interpret the absorption data specific to the programming period $2014-2020$.

The analysis methodology was based on the interpretation of the 3 existing absorption types, on the specificity of each operational program but also on the territorial distribution of absorption. The methodology was based on the application of mathematical and statistical formulas adapted to the specificity of the operational programs related to the Cohesion Policy 2014 - 2020. 6 operational programs were included in the analysis process, as follows: ROP, OPLI, OPC, OPHC, OPTA, OPAC.

\section{Literature review}

Cohesion policy is considered to be the EU's main investment instrument for achieving the "Europe 2020" objectives, which include: job creation and growth, combating climate change and energy dependence, and reducing poverty and social exclusion (European Commission, 2010). Defining Cohesion Policy is a difficult task, in particular due to its complexity but also due to the implementation process (Petcu et Roth, 2015). The concept of cohesion integrates the whole set of European 
policies aimed at reducing and eliminating disparities between Member States in order to generate a harmonious and balanced development throughout Europe (Ciocan V, Nuna, E., 2004).

Cohesion is understood as the degree to which the economic and social disparities between regions or groups of regions are tolerated politically and socially (Molle, 2007). The increasing importance of environmental issues and climate change has led to another definition of cohesion. Cohesion should not be interpreted exclusively from an economic point of view, as it must be implemented in close relation with social and environmental policies (Rakauskiene et all, 2011). The Treaty of Lisbon gives cohesion an understanding that integrates variables such as the economic, social but also territorial side, and admits the idea that Cohesion Policy must promote a more balanced development and at the same time a more sustainable territorial development. (Regio DG, 2014).

As can be seen, there are different views on the basic concepts specific to Cohesion Policy, referring here to the definition of cohesion itself and of the directions of action of Cohesion Policy. However, Cohesion Policy is one of the most important European policy. In this respect, the need for a cohesion policy will exist and will be of high importance (Berezi, 2016). In a context as dynamic as it is today, Cohesion Policy can play a complex and fundamental role for the future of the European Union (Berezi, 2016). Cohesion policy has the potential to generate a competitive advantage for companies, regions and countries and to develop human, intellectual and digital momentum (Olbrycht et all, 2011). Cohesion Policy will continue to play a pivotal role in these difficult times, with a view to delivering a smart, sustainable and inclusive growth process as well as a harmonious development process by reducing disparities. regionally (Rakauskiené and Ivashinenko, 2011).

The specialized literature does not deliver a generally accepted opinion on the efficiency of European funds, these being the main instrument with which European policies operate. Numerous studies have shown that structural funds have a positive impact on economic growth (Mohl \& Hagen, 2010; Eggert et al., 2007; Bouvet, 2005; Cappelen et al., 2003). While some studies support a clear connection between cohesion and convergence, others state a number of malfunctions regarding the European project and the policies that derive from it (Bostan et all, 2016).

Some authors do find evidence of a positive impact of structural funds on economic growth (eg, Dall'erba, 2005; Ramajo et al., 2008), others only find a weakly positive (eg, Esposti and Bussoletti, 2008), not statistically significant (eg, Dall'erba and Le Gallo, 2008) or even a negative impact (eg, Eggert et al., 2007). Regarding the economic impact of European Funds, the empirical literature (Boldrin and Canova, 2001; Checherita et al, 2009; Ederveen et al, 2006; Santos, 2008) generates different results. Boldrin and Canova (2001) find that European funds are on average ineffective.

The evaluation tools of the European Commission (guides, methodologies, etc.) are intended to support efforts to improve policy coordination in order to achieve greater effectiveness (Toderas \& Stăvaru, 2016). The thematic focus of

532 Review of International Comparative Management

Volume 20, Issue 5, December 2019 
resources on a few European priorities will not solve the whole set of dilemmas regarding the concept of cohesion, especially regarding the antagonism between regional equity and the competitiveness of the European economy (Begg, 2010).

The situation is similar in the case of factors that influence absorption, with fundamental differences from one Member State to another. There is no unanimously accepted opinion in the literature. Literature generally shows that the states' capacity to absorb European funds depends on the following main factors (NEI, 2002; Sumpikova, Pavel, and Klazar, 2003; Osterloh, 2010; Constantin, Goschin, and Dragan, 2011): administrative absorption capacity (related to the performance of public administrations at central, regional and local level, program design, project evaluation, coordination assurance between main partners and financing and implementation oversight, which means the management of a large amount of administrative activities), macroeconomic absorption capacity (the ability to generate sufficient investment opportunities to use European funds in an efficient way) and financial absorption capacity (the ability to co-finance these programs by the initial guarantee with funds from the national budget; moreover, it implies the collection of contributions from private or public partners interested in working on joint projects).

European funds are a subject of controversy, both in terms of their impact, the usefulness or even the definitions that underlie the way these funds are organized. The analyzes dedicated to European funds must thus focus on the institutional, programmatic and strategic specificity of the Member State.

\section{The main issues that characterize the absorption of European structural and investment funds}

\section{Co-financing and ineligible expenditure}

The issue of absorption must be addressed first and foremost by the financing structure, with European funds representing a source of funding that integrates at least two sources of funding, namely European funds and the national contribution to which additional contributions, private sources or ineligible expenses can be added. Also, European funds are spent on the basis of a synergy of interests materialized in the programmatic framework, respectively in the operational programs. This synergy of interests cannot cover the entire range of needs felt at the level of a sector or beneficiary so that the need to supplement European funding sources with complementary ones becomes an imperative to ensure a quality process regarding absorption. The financing structure regarding the projects contracted and financed by the main programs that form an integral part of the Cohesion Policy are mentioned in the table below. 
Table 1. The financing structure for the projects contracted on 31.12.2018

\begin{tabular}{|c|c|c|c|}
\hline \multirow{3}{*}{ Operational program } & \multicolumn{3}{|c|}{ ELIGIBLE value of the project (LEI) } \\
\hline & \multicolumn{2}{|c|}{ Financing granted } & \multirow{2}{*}{$\begin{array}{c}\text { The beneficiary's own } \\
\text { contribution }\end{array}$} \\
\hline & EU funds & National budget & \\
\hline $\begin{array}{l}\text { OPTA - Operational } \\
\text { Program for } \\
\text { Technical Assistance }\end{array}$ & $1.027 .144 .454,40$ & $4.338 .873,40$ & $180.376 .614,41$ \\
\hline $\begin{array}{l}\text { Operational Program } \\
\text { for Competitiveness }\end{array}$ & 3.621.387.530,09 & $725.216 .644,90$ & $574.388 .280,45$ \\
\hline $\begin{array}{l}\text { Operational Program } \\
\text { for Human Capital }\end{array}$ & 12.379 .038 .481 & 1.354 .932 .826 & 912.691 .540 \\
\hline $\begin{array}{c}\text { Regional Operational } \\
\text { Program }\end{array}$ & $18.275 .835 .074,33$ & $3.223 .304 .231,68$ & $2.732 .371 .192,61$ \\
\hline $\begin{array}{c}\text { Operational Program } \\
\text { for Large } \\
\text { Infrastructure } \\
\end{array}$ & $35.839 .973 .123,27$ & $1.894 .933 .185,10$ & 7.675.094.708,72 \\
\hline $\begin{array}{c}\text { Operational Program } \\
\text { for Administrative } \\
\text { capacity }\end{array}$ & $1.015 .747 .585,62$ & 23.496.331,18 & 168.696.909,91 \\
\hline
\end{tabular}

Source: Ministry of European Funds

Analyzing the financing structure of the projects funded from European funds we can observe significant differences from one operational program to another but also a different involvement of the beneficiary through their own contribution that they have to add to such a project.

Obviously, most of the funding comes from the budget of the European Commission, which, based on the shared management principle, finances the economic and social development processes agreed in the relationship with Romania. As of 31.12 2018, the budget of the European Union contributes within the projects financed with an amount of 72.159.126.248,72 lei while the national budget contributes with an amount of 7.226.222.092,26 lei. What is important to mention is the fact that projects contracted on 31.12.2018 involve a co-financing commitment from the beneficiaries in the amount of 12.243.619.246,11 lei, which is 5.017.397.153,84 lei higher than the sum assumed by the Member State. Basically, the entities in Romania that have the status of beneficiary within a project financed from European funds next to the state budget contribute 19.469.841.338,37 lei, representing $26.98 \%$ of the amount with which the budget of the European Commission contributes.

The beneficiary's contribution represents an obligation at its level, an obligation that derives mainly from the applicant's guide, an obligation that must be respected in order to be able to operationalize the project. The need for their own contribution is one of the most important problem for the stakeholders of the European funds in Romania because there are entities that, although they have significant eligible needs in the operational programs, they cannot apply because they do not have this co-financing. Reported at the level of the operational programs 
found under the Cohesion Policy, the beneficiary's contribution is greater than the contribution of the state budget. In addition to the need to ensure co-financing, the ineligible expenses are found. They have a different status than the co-financing and its additional character, practically representing a surplus of financial resources necessary for the implementation of projects funded from EU funds.

The role of these expenses is to finance those needs that are not covered by the programmatic documents and which are imperative for the operationalization of the investment financed through the project. Until. on 31.12.2018 the level of ineligible expenses assumed in the projects was 12.213.640.334,48 lei, approximately equal to the level of own contribution. The program that assumes the highest level of ineligible expenses is OPLI, their level being 9.491.480.161,98 lei followed by the ROP with 2.036.640.478,80 lei. Both operational programs concern the infrastructure, these types of projects carrying ineligible costs. The issue of cofinancing and ensuring the ineligible expenses is one of the most important problem found in the 2014-2020 programming period, the financial effort for beneficiaries being one, as has been seen substantially.

\section{Access to European financial resources}

The existence of operational programs that address a number of financing needs does not necessarily ensure the success of an absorption process. Assuming by a beneficiary the conditions imposed by the project, regardless of their nature, is a process that cannot be assured by all beneficiaries. Moreover, access to European funds is considered to be difficult, with a significant number of organizations that either do not meet the eligibility conditions or do not have the additional financial resources needed for a project funded from European funds. The managing authority through the management system and through the applicant's guide can influence access to European funds, access that can significantly influence the level of absorption. In this sense, the managing authorities frequently modify the eligibility conditions, implicitly the conditions of access to European funds.

The figure below provides a relevant picture regarding the distribution of contracts financed from European funds contracted from the programs related to Cohesion Policy during the implementation period 2014 - 2020. 


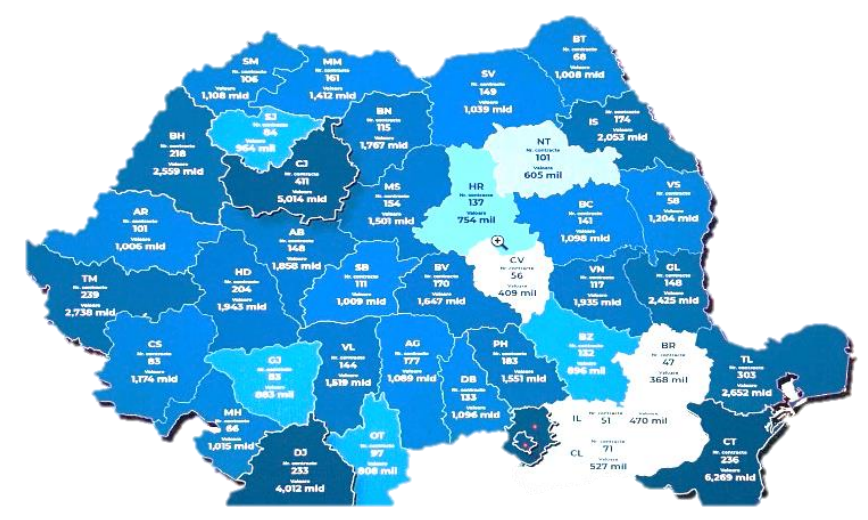

Figure 1. Projects contracted on 01.11.2019

Source: Ministry of European Funds

The distribution of the financing contracts signed on 01.11.2019 highlighted the fact that the counties considered to have a stronger economy benefited from higher amounts compared to the less economically developed counties. The most eloquent example is the Bucharest Ilfov region, which is a more developed region, one of the most developed in Romania. In Bucharest, 312 financing contracts were signed whose total value is 8.340 billion lei and Ilfov county benefited from 60 contracts whose cumulative value is 10.453 billion lei. Also, Constanta county has benefited from 236 financing contracts whose cumulative value is 6.269 billion lei and Cluj has benefited from 411 financing contracts whose cumulative value is 5.014 billion lei. Also, Dolj County, a county with an important industrial development benefited from 233 financing contracts with a value of 4.012 billion lei. The level of contracting is not necessarily converted into absorption, but it provides a clear picture of the concern and involvement of stakeholders in generating absorption. At the same time, Teleorman County has benefited from 53 projects financed from European funds whose value is 356 million lei, Braila of 47 contracts whose cumulative value is 368 million lei and Ialomita has benefited from 51 contracts whose value total was 470 million lei.

The figure above shows significant differences from one county to another in terms of the distribution of projects contracted during the 2014-2020 programming period also a distribution of funds to certain counties of the country. Moreover, the figure above shows that absorption will be concentrated in the developed counties of the country, these being the counties with the highest rates of contracting. Such a situation is one that undermines precisely the objectives of these funds, namely the reduction of regional inequalities and disparities. A concentration of contracting, implicitly of absorption in the developed counties, may be likely to deepen regional disparities and not reduce them. The way of managing the European funds through the management system does not direct the financing to those regions

536 Review of International Comparative Management

Volume 20, Issue 5, December 2019 
or poor counties that have much higher investment needs than counties such as Cluj or Ilfov. Thus, it is considered that access to European financial resources is a difficult one for the less developed counties, this being partially addressed by the management system of these funds.

\section{The situation of absorption}

A qualitative absorption that contributes to the attainment of the thematic and specific objectives established during the programming period 2014 - 2020 is, above all, a balanced absorption. The concept of balanced absorption is little addressed in the literature because there is no unanimous opinion on the concept of cohesion or on the usefulness or impact of European funds on economic growth and development. A coherent analysis of the absorption characteristics addresses both the absolute values of the absorption and the percentage values. Also, the approach of all the methods of calculating the absorption represents an element of maximum importance for the characterization of the absorption. The specificity of the operational program does not allow the acquisition of a clear image on absorption by inventorying the absolute values of absorption. Percentage of absorption is a variable that must be addressed in completing absolute values because the entire strategic and programmatic architecture is built on the principle of complementarity so that healthy absorption is an absorption that advances percentage in a roughly similar way for all operational programs within of a policy, in our case Cohesion Policy. The only exception to the above statement concerns OPTA because it must deliver a higher percentage of absorption in the first part of the programming period because of the specificity and coverage area that this program benefits from. In this respect, table 2 presents the absorption situation on 31.08 .2019 , it is presented as follows:

Table 2. The situation of absorption on 31.08.2019

\begin{tabular}{|c|c|c|c|c|c|c|c|}
\hline $\begin{array}{c}\text { Operational } \\
\text { programs } \\
\mathbf{2 0 1 4 - 2 0 2 0}\end{array}$ & $\begin{array}{c}\text { Allocation } \\
\mathbf{2 0 1 4 - 2 0 2 0} \\
\text { (EU) - euro }\end{array}$ & \multicolumn{2}{|c|}{$\begin{array}{c}\text { Payments to } \\
\text { beneficiaries } \\
\text { (EU) - euro }\end{array}$} & $\begin{array}{c}\text { Amounts requested } \\
\text { by the EC within the } \\
\text { limit of the EU } \\
\text { allocation of the OP } \\
\text { (current absorption } \\
\text { rate) - euro }\end{array}$ & $\begin{array}{c}\text { Reimbursements } \\
\text { from the EC } \\
\text { (effective absorption } \\
\text { rate) - euro }\end{array}$ \\
\hline ROP & 6.860 .000 .000 & 1.193 .123 .718 & $17,39 \%$ & 1.090 .298 .030 & $15,89 \%$ & 923.965 .685 & $13,47 \%$ \\
\hline OPLI & 9.218 .524 .484 & 1.939 .832 .193 & $21,04 \%$ & 1.859 .895 .710 & $20,18 \%$ & 1.671 .320 .358 & $18,13 \%$ \\
\hline OPC & 1.329 .787 .234 & 381.621 .247 & $28,70 \%$ & 267.197 .790 & $20,09 \%$ & 240.478 .011 & $18,08 \%$ \\
\hline OPHC & 4.371 .963 .027 & 1.052 .763 .966 & $24,08 \%$ & 801.714 .566 & $18,34 \%$ & 721.543 .109 & $16,50 \%$ \\
\hline OPAC & 553.191 .489 & 94.429 .552 & $17,07 \%$ & 88.523 .962 & $16,00 \%$ & 79.671 .565 & $14,40 \%$ \\
\hline OPTA & 252.765 .958 & 119.884 .989 & $47,43 \%$ & 115.627 .235 & $45,74 \%$ & 91.853 .623 & $36,34 \%$ \\
\hline
\end{tabular}

Review of International Comparative Management

Volume 20, Issue 5, December 2019 


\begin{tabular}{|c|c|c|c|c|c|c|c|}
\hline \multirow{2}{*}{$\begin{array}{c}\text { Operational } \\
\text { programs } \\
\mathbf{2 0 1 4 - 2 0 2 0} \\
\text { SUBTOTAL }\end{array}$} & \multirow{2}{*}{\begin{tabular}{|c|}
$\begin{array}{c}\text { Allocation } \\
\text { 2014-2020 } \\
\text { (EU) - euro }\end{array}$ \\
22.586 .232 .192
\end{tabular}} & \multicolumn{2}{|c|}{$\begin{array}{l}\text { Payments to } \\
\text { beneficiaries } \\
\text { (EU) - euro }\end{array}$} & \multicolumn{2}{|c|}{$\begin{array}{l}\text { Amounts requested } \\
\text { by the EC within the } \\
\text { limit of the } E U \\
\text { allocation of the OP } \\
\text { (current absorption } \\
\text { rate) - euro }\end{array}$} & \multicolumn{2}{|c|}{$\begin{array}{l}\text { Reimbursements } \\
\text { from the EC } \\
\text { (effective absorption } \\
\text { rate) - euro }\end{array}$} \\
\hline & & 4.781 .655 .666 & $21,17 \%$ & 4.223 .257 .294 & $18,70 \%$ & 3.728 .832 .351 & $16,51 \%$ \\
\hline
\end{tabular}

Source: Ministry of European Funds

At the operational program level, absorption rates create the premises for healthy, balanced absorption. Except for the OPTA program, rates show slight variations regardless of the type of absorption we refer to. However, the overall level of absorption rates is a very small one for the period in which the programming period is at this time. An extremely low level is a problem for the current programming period because it transfers the responsibilities of the programming period, here referring to reaching the indicators and spending targets towards the end of the programming period, which is considered a significant risk. Also, another issue of the current absorption on 31.08 .2019 concerns the relatively high differences between the payments made to the beneficiaries, the current and the actual absorption. In the case of ROP, the difference between the payments made to the beneficiaries and the current absorption is 1,5\% (102.825.688 euro) and between the payments made to the beneficiaries and the current absorption 3,92\% (269.158.033 euro).

OPHC registered a level of payments to beneficiaries of $24,08 \%$ (1.052.763.966 euro) and the actual absorption was only $16.5 \%$ (721.543.109 euro), the difference being $7,58 \%$ (1.052.763,966 euro). Also, the UCI recorded a level of payments to beneficiaries of $28.7 \%$ (381.621.247 euro) while the actual absorption is $18.8 \%$ ( 240.478 .011 euro), the difference being $10.61 \%$ ( 141.143 .236 euros). The mentioned differences prove a slow process of implementation at the project level, so the settlement process is much slower. Such a situation demonstrates a multitude of problems that characterize absorption such as managerial deficiencies at the level of managing authorities and intermediary bodies, poor organizational and technical capacity of the beneficiaries or the existence of a stubborn management system based on cumbersome and costly procedures both in terms of regarding the resources and the time required.

Another important aspect relates to the situation of absorption within an operational program, namely the evolution of absorption at the level of the priority axes. This is an unbalanced situation proven by the discrepancy in the evolution of absorption at the thematic objective level. We illustrate here the OPHC that contracted and generated a significant absorption within axis 3, neglecting the priority axis 1.2 or 6 . This situation has generated a significant absorption at the thematic objective regarding the competitiveness of SMEs placing Romania in the first states at European level and regarding the specific issues of job sustainability, it is on the last places at European level, the level of actual absorption at this thematic objective being a reduced one.

538 Review of International Comparative Management

Volume 20, Issue 5, December 2019 
The situation is similar in the case of the ROP where we benefit from a significant absorption within the axes 2.8 and 10 and in the case of the other axes the absorption is much lower. One of the particularities of the programming period 2014 - 2020 is the performance framework, this being for the first time introduced in the programmatic architecture of the structural funds. The need for synergy between what is financed and the economic and social needs has led to the use of such an instrument. This involves reallocating some money to the priority axes that have generated absorption and are in deficit of expenditures. Such an instrument proceeds to deepen the discrepancies between the priority axes, implicitly contributing to the consolidation of the absorption imbalance.

\section{Simplified costs}

The simplified costs measure is presented by the European Commission as a simplification measure at the operational programs level. This type of measure is one specific to the programming period 2014 - 2020, it was not possible to integrate this instrument in the previous programming period. This is mainly a measure dedicated to programs that interact with a large number of beneficiaries or that address a wide range of needs, the operational programs that have integrated such an instrument being OPHC and NRDP. Although promoted as a simplification tool, simplified costs can affect the quality of absorption or the impact of European funds. For example, a low level of scales on simplified costs for the qualification and retraining activity is rather a disadvantage for absorption.

The disadvantage derives from the fact that the absorption is slowed, which is evidenced by the absorption related to the thematic objective lifelong learning where on 01.11.2019 it benefited from a contracting rate of $104 \%(434,575,467$ euro) and the effective absorption was only $11 \%$ (46,270,273 euro). The large difference between the contracted value and the paid amount is an argument for the fact that the simplified costs instrument contributes to slowing the absorption by the low level that they deliver. Another disadvantage of simplified costs relates to the fact that, at least in the case of OPHC, it does not contribute to the structural reorientation of the economy because a low level of simplified costs does not ensure a high skills transfer process, the worker being kept in a situation who will acquire common skills and will be unable to support smart economic growth.

\section{Bureaucracy and procedural excess}

The bureaucracy and procedural excess are notoriously attributed to the management system specific to European funds, which derives both from the European Commission area and from the level of Romania. Bureaucracy is a consequence of a procedural overload that concerns both the area of administration and control of European funds.

Specific to the 2014 - 2020 programming period is the electronic data exchange between the beneficiary and the managing authority, which is a consequence of the European regulations. Although it was a measure dedicated to easy administration, the electronic data exchange resulted in a difficult situation for 
the beneficiaries. This electronic data exchange had to include the entire set of procedures specific to the European funds so that it became an applicant, generator of more bureaucracy and difficult to manage.

\section{The principle of complementarity}

One of the most important principles for absorption concerns the investment complementarity which aims at the synergistic support of investments financed from European funds. The consistency of such an approach is significant, but the applicability of such a principle is extremely difficult in a single-fund administration structure. Significant differences in absorption and contracting from one program to another make it extremely difficult to ensure complementarity between operational programs, which may constitute an irregularity in the relationship with the European Commission and may lead to disengagement of funds.

\section{Programming errors}

One of the problems that contribute to ensuring an absorption process that is not very correlated with the economic and social realities is the programming errors. They contribute to mitigating the impact of the European funds in the development processes against the background of financing projects with a reduced multiplication effect. The programming errors are based on the number of changes made at the level of the operational programs, these being annual in the case of certain operational programs. Also, the assertion related to the programming errors is also substantiated by the provision of disproportionate financial allocations in relation to the need at the economic and social environment level or in relation to the implementation capabilities.

A concrete example in this regard is the ROP where we can identify priority axes where the number of projects submitted is 500\% while others benefit from modest percentages in terms of contracting. The Integrated Territorial Investments instrument can also be considered a programming error, given that the amounts allocated to it are 1.11 billion euros and the affective absorption at the instrument level is modest, with the premise of the existence of a weak operational capacity in the territory served by the integrated territorial investments.

\section{Conclusions}

6.

The issue of European structural and investment funds is an intense topic debated in the literature, the approaches focusing mainly on the impact of the respective absorption on the capacity of the European funds to reduce inequalities and to generate development. Certainly, these elements are important for the strategic and programmatic architecture specific to the European funds, but this topic is an extremely complex one. Its complexity derives from the diversity of needs but also the institutional diversity with which the European funds interact. A high level of absorption of European funds at national level cannot be the attribute of a single

540 Review of International Comparative Management

Volume 20, Issue 5, December 2019 
institution but of an institutional architecture that integrates both public and private entities.

A complete analytical approach targeting the European funds cannot be achieved without taking into account the implementation capacities or more precisely those types of entities that assume the technical and procedural requirements specific to a project financed from European funds, which can significantly influence both the quality and the quantity of the level of absorption. The number of variables involved in the process of absorption of European funds is a significant one given the high complexity of this process.

Programming periods 2014 - 2020, the second programming period administered by Romania, is one that has significant challenges, which may affect the ability of European funds to contribute to economic development. The existence of a significant level of resources that a beneficiary of a project financed from European funds must use in the operationalization of the investment referring here to the applicant's contribution but also to the ineligible expenses are a major problem given the limited involvement of the state in these processes and of a budgetary context that is focused little on investment financing. A low level of absorption in general, which shows large differences between the amounts paid to beneficiaries and those settled by the European Commission, is also a major problem because of the growing need for liquidity that the operational programs will generate.

Bureaucracy, procedural inflation, programming errors but also simplified costs can be considered as problems with negative influences at the level of certain operational programs and implicitly of the programming period $2014-2020$ respectively of those programs that make up the Cohesion Policy. Another problem of absorption specific to the operational programs of the Cohesion Policy 2014 2020 is a directing of the European financial resources rather to the high development counties, negatively influencing the less developed counties but which have high investment needs.

The responsibility for a qualitative and at the same time high absorption represents an attribute at the level of all the interested actors existing between them a transfer of competences and assuming responsibilities specific to the European structural and investment funds.

\section{References}

1. Comisia Europeană, (2010), Intereconomics, 136-170. Europa 2020: Competitivitate, cooperare și coeziune între toate regiunile, 2010, Panorama inforegio.

2. Ciocan, V., Nuna, E., (2004). Instituţii europene. Noţiuni de drept comunitar, Editura GrafNet, Oradea, p. 259.

3. European Council, (1999), Presidency Conclusions, Berlin, 24 and 25 March 1999 
4. Cătălin Dumitru Petcu, Andrei Roth, (2015), The European union's cohesion policy: an east-central european perspective, On-line Journal Modelling the New Europe, Issue no. 14/2015.

5. Willem Molle, (2007), European Cohesion Policy, Routlegde, p. 6.

6. Comisia Europeană. (2014). Impactul politicii de coeziune 2007-2013: simulări realizate cu modelul econometric QUEST III, Pachet de lucru 4, DG Regio

7. Ona Gražina Rakauskienè, Nina Ivashinenko, (2011), The economic and social cohesion of the eu: methodology of investigation, Intellectual Economics, Vol. 5, No. 4(12), pp. 575-589

8. Mohl, P., \& Hagen, T. (2010). Do EU structural funds promote regional growth? New evidence from various panel data approaches. Regional Science and Urban Economics, 40 (5), 353-365.

9. Eggert, W., Von Ehrlich, M., Fenge, R., \& König, G. (2007). Konvergenz und Wachstumseffekte der europäischen Regionalpolitik in Deutschland. Perspektiven der Wirtschaftspolitik , 8 (2), 130-146.

10. Bouvet, F. (2005). European Union regional policy: Allocation determinants and effects on regional economic growth. Department of Economics, University of California, Davis.

11. Cappelen, A., Castellacci, F., Fagerberg, J., \& Verspagen, B. (2003). The impact of EU regional support on growth and convergence in the European Union. Journal of Common Market Studies , 41, 621-644.

12. Ionel Bostan, Cristian Popescu, Elena-Doina Dascălu, Bogdan-Narcis Firtescu, (2016), The European Union Cohesion Policy and External Migration in Romania. Multistage Analysis, Revista de cercetare și intervenție socială, 2016, vol. 54, pp. 96-114.

13. Nicolae Toderas, Ana-Maria Stavaru, (2016), Consolidation of eu governance: the european semester and the evaluation of european integration deepening, CES Working Papers - Volume VIII, Issue 1.

14. Berezi Elorrieta, (2016), New Roles for Cohesion Policy: A Useful Instrument at the Service of Economic Strategy and European Spatial Planning, , European Review, vol. 24, No. 4, 592-608, Academia Europæa.

15. Begg I (2010), Cohesion or Confusion: a policy searching for objectives, Journal of European Integration, 32:1, pp. 77-96

16. Jan Olbrycht, Magdalena Sapał, (2011), The future of the EU cohesion policy: how much, what for and how?, Centre for European Studies 2011, European View 10:241-248.

17. Ona Gražina Rakauskienè, Nina Ivashinenko, (2011), The economic and social cohesion of the eu: methodology of investigation, Intellectual Economics, Vol. 5, No. 4(12), pp. 575-589.

18. Netherlands Economic Institute (NEI), 'Absorption Capacity for Structural Funds in the Regions of Slovenia', Final Report Prepared for the National Agency for Regional Development of Slovenia, in the Framework of PHARE: Special Preparatory Program for Structural Funds in Slovenia, Ljubljana, 2002.

542 Review of International Comparative Management

Volume 20, Issue 5, December 2019 
19. Sumpikova, M., Pavel, J., and Klazar, S. (2003). EU Funds: Absorption Capacity and Effectiveness of Their Use, with Focus on Regional Level in the Czech Republic.

20. Conference on Problems facing the New Member States. Retrieved from http://unpan1. un.org/intradoc/groups/public/documents/nispacee/unpan018547.pdf.

21. Osterloh, S., 'The Fiscal Consequences of EU Cohesion Policy after 2013', 2010, Presupuesto y Gasto Público, No. 57/2009, pp. 77-98.

22. Constantin, D.L., Goschin, Z., \& Drăgan, G. (2011). Implications of EU Structural Assistance to New Member States on Regional Disparities: The Question of Absorption Capacity. In R. Stimson, R.R. Stough, \& P. Nijkamp (Eds.), Endogenous Regional Growth (pp. 182-203). Cheltenham, UK, Northampton, MA, USA: Edward Elgar Publishing Ltd., Cheltenham, UK, Northampton, MA, USA.

23. Dall'erba, S., 2005, Distribution of regional income and regional funds in Europe 1989-1999: an exploratory spatial data analysis. The Annals of Regional Science 39, 121-148.

24. Ramajo, J., Márquez, M., Hewings, G., Salinas, M., 2008, Spatial heterogeneity and interregional spillovers in the European Union: do cohesion policies encourage convergence across regions? European Economic Review 52, 551-567.

25. Esposti, R., Bussoletti, S., 2008, Impact of Objective 1 funds on regional growth convergence in the European Union: a panel-data approach. Regional Studies $42(2), 159-173$.

26. Dall'erba, S., Le Gallo, J., 2008, Regional convergence and the impact of European structural funds 1989-1999: a spatial econometric analysis. Papers in Regional Science 82 (2), 219-244.

27. Eggert, W., von Ehrlich, M., Fenge, R., König, G., 2007, Konvergenz- und Wachstumseffekte der europäischen Regionalpolitik in Deutschland. Perspektiven der Wirtschaftspolitik 8 (2), 130-146.

28. Boldrin, M., and Canova, F., 2001, Europe's Regions: Income Disparities and Regional Policies, Economic Policy vol. 16 (32), pp. 207-53

29. Checherita, C., Nickel, C., and Rother, P., 2009, The role of fiscal transfers for regional economic convergence in Europe, ECB Working Paper Series no. 1029, European Central Bank

30. Ederveen S., Groot, H.L.F., and Nahuis, R., 2006, Fertile Soil for Structural Funds? A Panel Data Analysis of the Conditional Effectiveness of European Cohesion Policy, Kyklos vol 59(1), pp. 17-42, 02, Blackwell Publishing

31. Santos, I., 2008, Is Structural Spending On Solid Foundations?, Policy Brief 02/2008, Bruegel 